Đorđe Čekrlija ${ }^{1}$

doi: $10.5937 /$ Civitas1701013C

Dijana Đurić ${ }^{2}$

UDC 159.923

Biljana Mirković ${ }^{3}$

\title{
VALIDATION OF ADLERIAN INFERIORITY (COMPIN) AND SUPERIORITY (SUCOMP) COMPLEX SHORTENED SCALES
}

\begin{abstract}
The main purpose of this study is to examine the inferiority and superiority complex scales, and develop their shortened versions. For this purpose two studies were conducted. In the first study, 395 students (62\% female) were tested, and the inferiority (COMPIN, 40 items) and superiority complex (SUCOMP, 38 items) scales were analyzed. The examination of their psychometric properties indicated satisfactory psychometric features. Based on the values of communality, item-total correlation and scale principal component saturation, ten items were chosen for shortened scales. The exploratory factor analysis of the shortened scales clearly identified two factors that represent inferiority and superiority complex. In the second study, the sample consisted of 187 students (53\% female). A confirmative factor analysis was carried out. The structural model consists of two correlated, identifiable dimensions and adequate fit indicators. Overall results sugest that the Adlerian concepts are adequately operationalized in COMPIN and SUCOPM scales. These scales can be valuable research tools in psychological research. Furthermore, shortened COMPIN-10 and SUCOMP-10 scales seem to be useful tools for measuring the inferiority and superiority complex.
\end{abstract}

\footnotetext{
${ }^{1}$ Filozofski fakultet, Univerzitet u Banjoj Luci, djopsi@gmail.com

2 ZFMR Dr Miroslav Zotović, Banja Luka

${ }^{3}$ Filozofski fakultet, Univerzitet u Banjoj Luci

This is an Open Access article distributed under the terms of the Creative Commons Attribution License (http://creativecommons.org/licenses/by/4.0/), which permits unrestricted use, distribution, and reproduction in any medium, provided the original work is properly cited.
} 
KeY wORDS: Inferiority and superiority complex, COMPIN and SUCOMP scales, validation.

\section{Introduction}

Despite the importance of individual psychology, the Adlerian concepts are rather infrequently used in empirical research. Although they can be adequately psychometrically operationalized (Ignjatović, Momirović \& Hošek 1995; Mitrović, 2004), as well as the constructs from other psychodynamic theories (Grygier, 1956; Ignjatović te al., 2001; Čekrlija, 2011; Momirović et al., 1975, 1976), they remain at the margins of scientific interest. Current research trends in personality psychology is focused on personality models such as: Big Three (Eysenck \& Eysenck, 1975), Big Five (Goldberg, 1990; Costa \& McCrea, 1992; Zuckerman, 2002) Big Six (Lee \& Ashton, 2004) or Big Seven personality dimensions (Almagor, Tellegen \& Waller, 1995; Goldberg \& Somer, 2000; Smederevac, Mitrović \& Čolović, 2010; Saucier, 1997). Predominant research problems are the structure of personality traits, description of their substructures, and relationship with other psychological constructs. At the same time, we can say that most of these models treat personality traits like psychological postulates. Current research has been focused on the structure of personality traits, while the origins and phylogenetic age of basic traits, their developmental processes, and dynamic interpretations of their relationship with other psychological and sociological factors seem to be of less interest to researchers. Besides, personality models are for the most part used and examined by academically oriented researchers, while psychotherapy and counselling mostly focus on constructs developed in psychodynamic theories (like individual psychology). Interestingly, however, personality factorial models and psychodynamic theories are not incompatible. Interpretations and explanations derived from their platforms are frequently consistent with each other (Mitrović, Jevremov \& Vasić, 1997; Mitrović, Trogrlić \& Todosijević, 1997). Considering that both of these fields have a solid position in psychology, it seems wrong to keep them separated.

The central concept of the Adlerian theory of personality is the feeling of inferiority (Adler, 1989). It is based on a real feeling of incom- 
petence and absolute dependence we experience as infants and children. This feeling is triggered by the child's perception that others possess all the power, and that struggling against that kind of power is hopeless. As a result, the child feels inferior and less capable. In real life situations, inferiority feeling triggers the compensatory processes, with the aim to overcome the feelings of inadequacy. According to Adler, life style is the crucial factor that can lead to the feeling of inferiority. In the case of inferiority, the feeling of inadequacy activates compensation, while the superiority feeling triggers over-compensation. Inferiority and superiority complexes can exist simultaneously, and while one of them is manifest, the other one remains hidden. The main function of the inferiority feeling is to activate compensatory processes that make a person want to improve, grow and overcome their perceived weakness. On the other hand, the purpose of both the inferiority and superiority complex is to protect the self from the feelings of inferiority. Thus the inferiority complex can lead to a personality style made of justifications and alibis. With the superiority complex, the feeling of inadequacy is hidden and replaced by an impression of personal superiority.

The empirical data gathered so far suggest that the infantile inferiority feeling, inferiority and superiority complexes can be adequately operationalized for empirical examination. The analysis of superiority complex (SUCOMP) scale confirmed the existence of this construct and its valid psychometric features (Mihić \& Mitrović, 1996; Mihić, Višekruna \& Mitrović, 1996). The results also suggest that SUCOMP can be adjusted for school age respondents (Vasić, Veljković \& Trogrlić, 2005). Šakotić and Karanjac (1999) confirmed the validation of the scale COMPIN and identified its valid psychometric properties. A taxonomic analysis of the infantile inferiority feeling, inferiority and superiority complex scales (Ignjatović, Momirović \& Hošek, 1995) indicated that more than $97 \%$ of respondents were classified corectly. Mitrović (1998) reexamined all the scales related to feelings of inferiority. According to her findings, COMPIN and SUCOMP are consistent to basic concepts of Adlerian individual psychology and display valid properties.

The first validation study examined the relationship betwen the Adlerian complexes and Freudian libido fixations. Both authors insisted on the dynamic interpretation of personality system, and both of them 
are neglected in the research based on multivariate methodology. The results obtained indicated the existance of a relationship between the inferiority complex and the Oedipus/Electra problems, oral-passive, and anal-retentive fixation (Višekruna, 1996; Višekruna, Trogrlić \& Vasić, 1996), while the superiority complex was related to the Oedipus complex, oral-aggressive and anal-aggressive fixation (Ignjatović \& Višekruna, 1966; Štrbac, Kosanović \& Vasić, 1996). On the other hand, the analysis of relations with basic personality traits derived from Eysencks' PEN model, indicated a relationship between some domains from $\mathrm{P}$ and N scales with the inferiority feeling (Ignjatović, Delić \& Trogrlić, 1996; Jevremov, 1997; Šakotić \& Ruk, 1997). Kosanović and Šakotić (1996), and Šakotić, Kurbalija and Barišić (1997) added the results which emphasized the relationship between the inferiority feeling and introverted behavior. According to Ruk and Momčilov (1996), the superiority complex was related to normative morality as a substructure from the $\mathrm{P}$ scale. In further validation studies, the findings have emphasized a consistent relationship between the inferiority complex and the freezing anxiety (Radočaj \& Vasić, 1998; Vasić \& Radočaj, 1998), the excitatory anxiety (Momčilov \& Krpović, 1995), as well as a relationship between the superiority complex and excitatory anxiety (Todosijević \& Knebl, 1998). The study of the relationship between the superiority feeling and authoritarian personality symptoms, reported by Mitrović and Barišić (1997), led to the conclusion that the superiority complex could not be reduced to authoritarianism. The COMPIN and SUCOMP scales have also proved their predicted value of anxiety (Jevremov \& Todosijević, 1998) and partners' relationship (Šakotić \& Kurbalija, 2011).

The collected findings indicate that the COMPIN and SUCOMP scales are adequate measuring tools for the inferiority and superiority complex, with satisfactory psychometric characteristics, and consistent to Alderian theoretical concepts. They seem to be useful tools in the empirical analysis of personality. We propose that these scales could provide a new qualitative aspect to the considerations of basic traits in the frame of personality models.

The main aim of studies conducted is to examine whether the COMPIN and SUCOMP scales can be reduced to shorter, 10 -items versions. As the scales comply with the Adlerian theory and exibit valid 
metric characteristics, we came to the idea to form shorter questionnaire versions. The scales would probably remain unidimensional, so as not to lose too many of their psychometric characteristics, but they would become much more practical to use. Gosling et al. (Gosling, Rentfrow \& Swann, 2003) emphasize that short measures of personality traits are equally valid as the estimations based on longer questionnaires. For example, Rosenberg's 10-item scale (Rosenberg, 1965) is probably the most used self-esteem measure. John and Svrsistava (1999) created the BFI-10 scale which includes measures of all Big Five personality factors. The most radical example is the single item self-concept scale (Robins, Hendin, \& Trzesniewski, 2001). Using the original versions is certainly preferrable, but it is expected that shorter inferiority and superiority scales will provide adequate insight into certain personality processes.

\section{Study 1}

The main aim of this study is to examine psychometric properties of the COMPIN (Mitrović, 1998) and SUCOMP (Mitrović, 1998) scales in order to identify which items to include in the shortened versions. Previous studies have shown that both scales are unidimensional. Therefore, we expected to single out items with the best psychometric properties for shortened versions of both instruments.

\section{Method}

\section{Sample and Procedure}

The sample consisted of 395 students (62\% female) from Banja Luka University, between 20 and 32 years old $(\mathrm{M}=22.93, \mathrm{SD}=1.13)$. The students completed questionnaires after their regular classes. Participation in the research was completelly voluntary and anonymous.

\section{Instruments}

Two questionnaires were administered. The COMPIN scale (Mitrović, 1998) consisting of 38 items was used in the inferiority complex estimantion, while the superiority complex was assesed with the 40-item scale SUCOMP (Mitrović, 1998). Both scales indicate satisfactory Cronbach a coefficients of reliability (COMPIN, $\alpha=.92$, and SUCOMP, $\alpha=.93$ ). 


\section{Data Analysis}

In the first step the COMPIN and SUCOMP scales were examined separately. The purpose was to examine whether scales could be adequately operationalised through a single dimension, and second, whether it was possible to single out adequate items for shortened versions. A descriptive statistical analysis was conducted first. The internal consistency of scales was examined using a reliability analysis. Next, a principal component analysis for both scales was carried out. As the previous analysis suggests, both scales proved suitable for reduction. The values of communality coefficients, principle components loadings and item-total correlation coefficients were proposed as the criteria for the reduction process that would result in a 10-item version of both scales.

An exploratory factor analysis was performed to check the factorial structure of the COMPIN and SUCOMP shortened 10 -item version scales. The principal component method was used in factor extraction and scree test in the identification of significant factors. The extracted factors were rotated in the promax position. The exploratory factor analysis was expected to indicate whether it was possible to replicate the two separate dimensions clearly representing the inferiority and superiority complex operationalized by the COMPIN and SUCOMP short version scales.

\section{Results}

The following data examination involved an analysis of parameters meant to be used in scales reduction. Therefore, descriptive statistics were analysed. Average item scores were ranged between 1.62 and 2.58 for the inferiority complex and between 1.89 and 4.11 for superiority complex scale (table 1). Three items in the COMPIN scale (items 11, 16 and 21) showed significant skew indexes. The SUCOMP scale items indicated lower skew index values.

The first principal component was better defined and higher saturated for the COMPIN scale and could explain the $45 \%$ of variance. The SUCOMP scale first component could explain $32 \%$ of total variance. The factor loadings were in a range between .42 and .81 for the COMPIN, and from .32 to .76 for the SUCOPM scale. Generally, item-total correlation was satisfactory for both scales. Higher values were registrated for 
Table 1. Items descriptive statistics and first principal component (comunalities and factor saturations)

\begin{tabular}{|c|c|c|c|c|c|c|c|c|c|c|c|c|c|c|c|}
\hline & $M$ & $\bar{D}$ & $S$ & K & $\mathrm{c}$ & & I PC & & $\bar{M}$ & $\mathrm{SD}$ & S & K & $\mathrm{c}$ & $\mathrm{r}$ & I PC \\
\hline & 2.19 & 90 & 88 & .92 & .62 & & 64 & & 1 & .69 & -.15 & 34 & .29 & 10 & .32 \\
\hline OMPIN2 & 02 & 90 & 1.10 & 1.59 & 6 & & 69 & 2 & 13 & .93 & -.27 & -.49 & .50 & 28 & .53 \\
\hline COMPIN3 & 42 & 1.18 & .43 & -.73 & .63 & 13 & .66 & UCOMP3 & 56 & .92 & -.17 & -.06 & .53 & 33 & .58 \\
\hline COMPIN4 & 2.00 & 1.03 & .64 & -.54 & .64 & 45 & .67 & SUCOMP4 & 50 & .80 & -.23 & .91 & .56 & 35 & .59 \\
\hline COMPIN5 & 2.05 & 1.00 & .66 & -.33 & .65 & 46 & .68 & SUCOMP5 & 2.93 & .82 & -.29 & .57 & .43 & .21 & .46 \\
\hline COMPIN6 & 2.42 & 1.25 & .67 & -.62 & .64 & .43 & .66 & $\mathrm{UC}$ & 31 & .95 & -.54 & .43 & .37 & .17 & .41 \\
\hline IN7 & 2.26 & 1.07 & .66 & -.40 & .66 & 46 & .68 & SUC & 3.38 & 1.00 & -.24 & -.71 & .58 & .39 & .62 \\
\hline $\mathrm{COM}$ & 18 & .97 & .93 & .60 & .67 & .48 & .69 & SUC & 2.81 & .87 & .02 & -.15 & .5 & .31 & .56 \\
\hline CON & 2.51 & 1.11 & .34 & -.85 & .70 & 51 & .72 & SUC & 99 & .86 & -.60 & .74 & 6 & .43 & 66 \\
\hline $\mathrm{COM}$ & 107 & .91 & 54 & -.4 & 67 & & .70 & & 2.87 & 1.0 & 16 & -.99 & .53 & .33 & .57 \\
\hline & 78 & 88 & & 2.8 & 68 & & .71 & & & 91 & .50 & .74 & & & .52 \\
\hline & 23 & & .67 & -.39 & .68 & & 69 & & & .86 & -.22 & 0 & 58 & & 62 \\
\hline & & & & .33 & & & 49 & & & 36 & -.35 & .18 & & & .66 \\
\hline & 22 & 21 & 71 & -.62 & .7 & & .80 & & & 94 & 50 & 85 & & & .62 \\
\hline $\mathrm{CO}$ & 86 & 91 & 1.2 & 1.77 & .64 & .45 & .67 & & & .92 & -.01 & -.2 & .5 & .37 & .61 \\
\hline COMPIN16 & 1.86 & .82 & 1.17 & 2.01 & 68 & .49 & .70 & SUCOMP16 & 3.83 & .91 & -.45 & -.47 & .31 & .11 & .33 \\
\hline COMPIN17 & 2.58 & 1.15 & .31 & -.79 & .51 & .27 & .52 & SUCOMP17 & 2.26 & .81 & -.06 & -.68 & .62 & .42 & .65 \\
\hline COMPIN18 & 1.99 & 1.10 & 1.06 & .34 & .73 & .57 & .75 & SUC & 2.26 & .91 & .53 & .34 & .72 & .58 & .76 \\
\hline $\mathrm{COM}$ & 1.98 & .90 & .92 & .76 & .60 & .39 & .63 & SUC & 2.67 & .97 & .21 & -.63 & .65 & 47 & 68 \\
\hline J20 & 2.13 & .97 & .84 & .43 & .60 & 4 & .63 & SU & 1.91 & 1.01 & 1.32 & 1.74 & .43 & .23 & .48 \\
\hline C & 99 & .87 & 1.57 & 2.29 & .6 & 51 & .71 & SUCOMP21 & 39 & .79 & .44 & 9 & .64 & .44 & .66 \\
\hline C & .14 & .09 & .92 & .24 & .79 & 65 & .81 & SUCOMP22 & 7 & .88 & .24 & 3 & .57 & .37 & .61 \\
\hline 23 & 82 & 88 & 93 & .21 & .65 & 16 & .68 & SU & 2.28 & .98 & .66 & .04 & .65 & 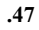 & .69 \\
\hline 4 & 2.47 & 1.15 & .66 & 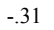 & .66 & 16 & .68 & SUCO & 3.04 & 1.18 & -.22 & -1.05 & .4 & .30 & .55 \\
\hline N25 & .93 & .84 & 67 & -.07 & 50 & & .57 & & 2,1 & 1.08 & -.20 & -.40 & .5 & & .62 \\
\hline N26 & .12 & 1.01 & .55 & -.49 & .59 & & .61 & SUC & .07 & .95 & 1.09 & 1.11 & .47 & .2 & .51 \\
\hline $\mathrm{COM}$ & 2.09 & .99 & .74 & .18 & .63 & & .66 & SUC & 44 & 1.02 & .21 & -.58 & .63 & .44 & .66 \\
\hline COMPIN28 & 2.11 & .98 & .45 & -.52 & .60 & .3 & .63 & SUC & 3.26 & 1.07 & -.26 & -.51 & .49 & .28 & .52 \\
\hline CON & 87 & .95 & 1.23 & 1.47 & .73 & .57 & .75 & SUC & 3.26 & 1.10 & -.28 & -.41 & .44 & .20 & .45 \\
\hline $\mathrm{CON}$ & 1.62 & .77 & .77 & -.88 & .56 & .34 & .59 & SUC & 2.93 & 1.03 & -.07 & .13 & .58 & .36 & .60 \\
\hline COMPIN31 & 2.39 & 1.25 & .59 & -.81 & .62 & 41 & .64 & SUCC & 2.54 & 1.21 & .44 & -.67 & .32 & .11 & .33 \\
\hline $\mathrm{COM}$ & 2.04 & .99 & .95 & .51 & 63 & .42 & .65 & SUC & 2 & 1 & .10 & -.90 & .47 & 23 & .47 \\
\hline N33 & 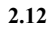 & 0 & 80 & 15 & .7 & 54 & .73 & SUC & 3.85 & .96 & -.76 & .39 & .42 & 10 & .44 \\
\hline $\mathrm{CO}$ & 6 & 112 & .41 & 89 & .68 & 48 & .70 & Sur & 26 & 1. & .32 & .11 & 46 & 2 & .50 \\
\hline 5 & 2 & ) & .8 & -.26 & .70 & & .72 & Sur & 296 & 1.06 & -.1 & -1.0 & 44 & 21 & 46 \\
\hline 36 & 2 & 1.13 & .74 & -.50 & 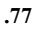 & & .78 & SUCOMP36 & 2.52 & .99 & .13 & -.45 & .53 & 2 & .57 \\
\hline & 1.89 & .95 & .96 & .41 & .52 & & .53 & & 3.41 & 1 & -.45 &.- & 63 & & 66 \\
\hline & 1.82 & .90 & .89 & -.0 & .66 & & .67 & SUCOMP38 & 2.20 & 1.03 & .74 & .34 & .48 & .25 & .50 \\
\hline & 1. & & 1.16 & .7 & .53 & & . & & & & & & & & \\
\hline COMPIN40 & 4 & 1.05 & .99 & .22 & .6 & .4 & .70 & & & & & & & & \\
\hline
\end{tabular}

NOTE: $c=$ comunality; $r$ = corrected item-total correltation; Items selected for shortened versions are given in bold. 
the COMPIN items (from .51 to .79). The values for the SUCOMP items were also satisfactory but in a greater range (.29 to . 72$)$.

In accordance with the aim of the study, three basic criteria were chosen: communalities, factor loadings and item-total correlation. In the COMPIN scale, the ten items selected for shorthened version showed the highest values on all three criteria. In the SUCOMP scale, the nine selected items had the highest values on all criteria, while item 7 was selected on the base of comunalities and factor loading values. The overall examination proved that both scales had a robust first principal component suitable for shorter version construction.

Two dimensions, suggested by the scree test, were extracted in the exploratory factor analysis of the shortened COMPIN and SUCOMP scales. They explained $53 \%$ of variance (first factor, $31 \%$ ). Table 2 provides clear evidence that factors were highly saturated with items from different scales. The first factor was defined by high correlations with all COMPIN items and one negative relation with item SUCOMP17. We considered this to be an adequate operationalization of the inferiority complex. The saturations on the second factor were also very high. Since all items from SUCOMP scale define it, the second factor was taken to represent the superiority complex factor. The correlation between the factors defined as inferiority and superiority complex was -.16. Generally speaking, the exploratory factor analysis clearly suggests that the shortened COMPIN and SUCOMP scales measure separate dimensions that could be described as the inferiority and the superiority complex, and adequately represent the original scale.

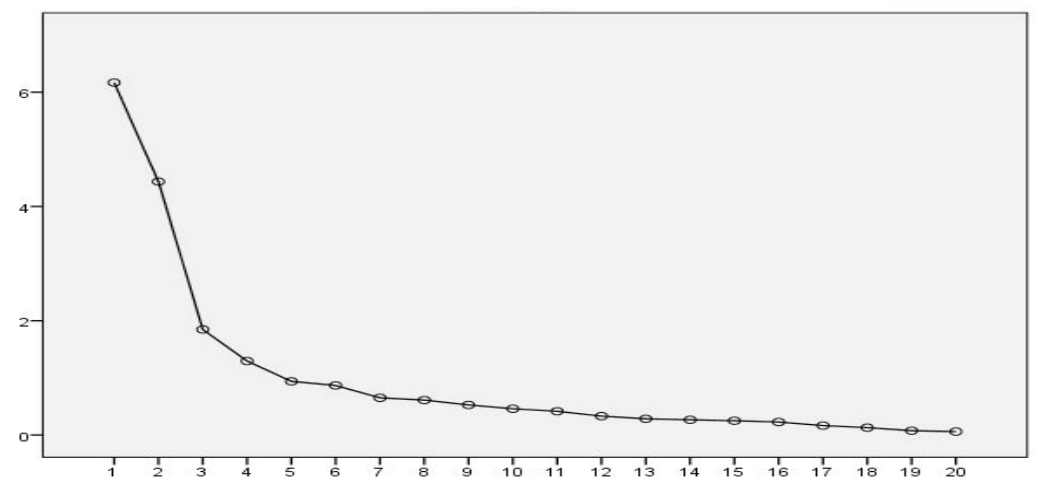

Figure 1. Scree plot 
Table 2. Exploratory factor analysis of COMPIN-10 \& SUCOMP-10 scales

\begin{tabular}{lcc}
\hline & I & II \\
\hline COMPIN9 & .71 & \\
COMPIN14 & .86 & \\
COMPIN17 & .63 & \\
COMPIN18 & .71 & \\
COMPIN21 & .68 & \\
COMPIN22 & .77 & \\
COMPIN29 & .66 & \\
COMPIN35 & .72 & \\
COMPIN36 & .84 & \\
COMPIN33 & .74 & \\
SUCOMP7 & & .69 \\
SUCOMP9 & & .66 \\
SUCOMP13 & & .73 \\
SUCOMP17 & -.41 & .61 \\
SUCOMP18 & & .85 \\
SUCOMP19 & & .70 \\
SUCOMP21 & & .78 \\
SUCOMP23 & & .68 \\
SUCOMP27 & & .70 \\
SUCOMP29 & & .55 \\
\hline NOTE: Original item numbers were retained.
\end{tabular}

\section{Discussion}

The main research goal was to identify the COMPIN and SUCOMP items with best psychometric properties for the shortened questionnaires version. Both examined scales indicate acceptable psychometric properties. At first, the reliability coefficients are very high and similar to previous studies (Barišić \& Kosanović, 1996; Mihić \& Mitrović, 1996; Momčilov, Radočaj, 1999), as well as the first principal component structure of both scales (Mitrović, 1998). In the process of scales reduction, the following three criteria were used: communalities, first component loadings and item-total correlation, which were in accordance. Generally, the first principal component is well defined on both 
scales. Comunalities and factor loadings are higher on the COMPIN items. Besides, the factor loadings on the SUCOMP scale are in a wider range, and it was easier to identify which items should be kept. Item-total correlations are also higher on the COMPIN scale. At the same time, the lack of confidence and low self-esteem comprise the structure of the first principal component on the COMPIN scale. Cognitive superiority and impression of personal importance, as well as dominance over other people, are the indicators that show the highest factor loadings on the SUCOMP scale. The minimal value of coefficient for selected items is .70. The same parametar values are generally lower on the SUCOMP items, but still in a satisfactory range.

The factor analysis conducted on the shortened scale versions identified two factors that absolutely match the scales' principal components. A single item (SUCOMP17, Only rarely have people had as much success as I did) defines both factors. Once again, the low self-esteem indicators have the most significant loads on this latent dimension. On the other hand, the items related to feeling of personal omnipotence show the highest loadings on the SUCOMP latent dimension. From the theoretical perspective, the extracted factors on both scales can be accepted as a measure of the inferiority and superiority complex. Scales reduction did not decrease construct or divergent validity. The inferiority and superiority complex indicators are still well represented and clearly separated from each other.

The first study results indicate that the COMPIN and SUCOMP shortnened version scales could be used in the inferiority and superiority complex assessment. In order to obtain relevant confirmation, a convergent and divergent validity examination should be carried out.

\section{Study 2}

In the second study, we analyzed the basic psychometric properties and dimensionality of the COMPIN-10 and SUCOMP-10 scales. We tested if the shortened inferiority and superiority scales replicated psychometric properties from the original versions. Therefore, this part of research could be a valuable contribution to the further examination of Adlerian concepts, and could prove useful in the validation process of both questionnaires. 


\section{Method}

\section{Sample and Procedure}

The second study sample consisted of 187 students (53\% female). The data was collected online using the snowballing technique. The online questionnaire link was sent to psychology students at the University of Banja Luka, who in turn forwarded it to their web contacts. All the data was collected within seven days. The respondents were between and 19 and 41 years old $(M=25.12, S D=4.49)$. Participation was voluntary and anonymous.

\section{Instruments}

Shorter versions of the inferiority and superiority complex scales were used in this study. The 10-item version of the COMPIN was used as a measure of the inferiority complex and the 10 -items version of the SUCOMP was used in measuring the superiority complex. The shorter inferiority and superiority complex scales maintain a high reliability, as Cronbach $\alpha$ coefficients indicate (COMPIN-10, $\alpha=.90$ i SUCOMP-10, $\alpha=.88$ ).

\section{Data Analysis}

The shortened versions of the inferiority (COMPIN-10) and superiority complex scales (SUCOMP-10) were examined through the exploratory and confirmatory factor analyses. The purpose was to examine whether the short scales exibit tendencies consistent with the original versions findings.

\section{Results}

The common factorial structure of the COMPIN-10 and SUCOMP-10 was first examined using the exploratory factor analysis using principal components method. The scree test suggested a clear two-factorial solution, which was consistent with previous study findings. Kaiser-Meyer-Olkin measure (.72) implies that the scales were adequately represented, while the Bartletts sphericity test $\left(\chi^{2}(435)=\right.$ $1963.33, \mathrm{p}<.00)$ indicates that data reduction was justified. The two factors explained $65.44 \%$ of variance. 
In order to retest the common factorial structure of the COMPIN-10 and SUCOMP-10 scales hypothesis, the confirmatory factor analysis was conducted. We tested only one model with two correlated latent variables which were supposed to represent the inferiority and superiority complex (table 4 ). Each item was linked to a single factor. The estimation method was Maximum Likelihood, calculated on covariance matrix. $\chi^{2} / \mathrm{df}$ ratio is in agreement with the proposed good fit indicator $\leq 3.00$ (Kline, 2005). The RMSEA and SRMR values indicate a good fit between empirical results and theoretically proposed structure (acceptable values <.10). The index of fit (GFI) and comparative fit index (CFI) are above the suggested limit of explained variance.

Table 3. Confirmatory factor analysis fit parameters

\begin{tabular}{cccccccc}
\hline$\chi^{2}$ & $\mathrm{df}$ & $\mathrm{p}$ & $\chi^{2} / \mathrm{df}$ & GFI & CFI & $\begin{array}{c}\text { RMSEA } \\
(90 \% \mathrm{CI})\end{array}$ & SRMR \\
\hline 312.913 & 169 & .00 & 1.86 & .91 & .92 & $.09(.08-.10)$ & .08 \\
\hline
\end{tabular}

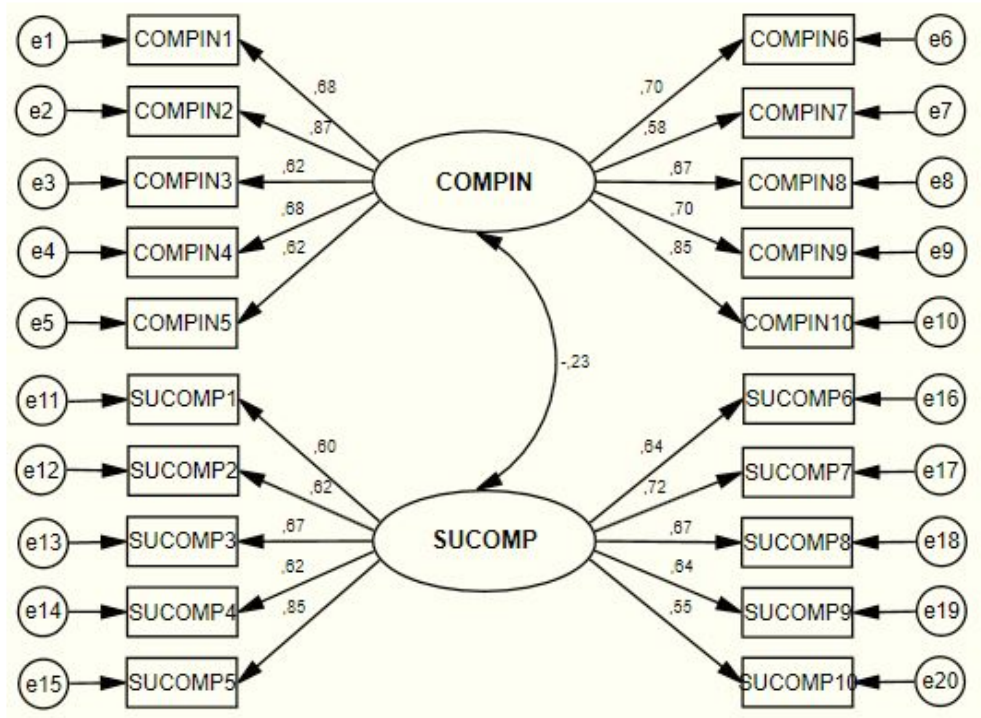

Figure 2. Factor loadings on inferiority and superiority complex scale factors 
As figure 2 shows, the COMPIN and SUCOPM items were strictly divided into two latent variables. Both latent variables were highly saturated by all items from corresponding scale. As expected, negative weak correlations (-.23) were registered between latent variables. Confirmed latent variables structure (figure 2) were completely in accordance with the previous findings of the COMPIN and SUCOMP scales, as well as compatible with the Adlerian theoretical concept of inferiority and superiority complex.

\section{Discusion}

Previous research has rarely dealt with questionnaire operationalization of Adlerian concepts. The main goal of the present study was to examine the shortened versions of inferiority and superiority complex scales (named COMPIN-10 and SUCOMP-10). In general, the results presented here were congruent with the results from the previous study with the COMPIN and SUCOMP (Mitrović, 1998).

The structure of the first latent dimension defined by all COMPIN-10 items absolutely corresponds with the inferiority complex. Factor accounts for low self-esteem, inferiority feeling and defense mechanisms. Items 2 (I am aware how much I know about myself, but I cannot deal with it) and 10 (I have no self-confidence) show the highest loads on the latent dimension. Indicators of regression and rationalization also show high values and indicate a general misanthropy as a life style and a attitude towards any challenge.

The second latent variable corresponds to the superiority complex. Indicators of personal omnipotention are highly loaded on factor? The content of items 5 (Few people can compare with me) and 7 (Normally no solution can be found without me) clearly presents the importance of the feeling of omnipotence in determining the existance of the superiority complex. Competitiveness and self-confidence are high loads factors as well. The content of the second latent variable defined by the SUCOMP-10 items match the principal superiority complex factor reported in the previous studyt with the SUCOMP (Ignjatović, Delić, \& Momirović, 1995; Mitrović, 1998, Trogrlić \& Krpović, 1999). 
The correlations between latent dimensions are similar to the previous studies of the relationship between the inferiority and superiority complex (Barišić, 1996; Ignjatović, Momirović, \& Hošek, 1995; Mitrović, 1998). It confirms the Adlerian assumptions on the nature of their relationship. The correlation of -.23 between the superiority and inferiority complex emphasizes their simultaneous existence. The negative correlation should be an indicator of overcompensation, which helps a person overcome the original feelling of inferiority. This also helps indicate the distinction between inferiority and superiority attitude.

\section{General Discussion}

The main goal of the studies presented in this paper was the construction of the shortened inferiority (COMPIN-10) and superiority (SUCOMP-10) complex scales. Although the original versions have yielded well-grounded results and a solid insight in the Adlerian complex so far, we deemed it desirable to have shorter scales for quick assessment. The valid characteristics of original versions provide the easy selection of items for shortened scales. Analogously, shortened scale versions indicate valid psychometric properties, consistent to the original scales. Furthermore, contents of extracted dimensions are in accordance with the Alderian conceptualization of the inferiority and superiority complex. Finally, as a brief operationalization of Adlerian basic concepts, the shortened scales can be easilly included in personality model assessment. In light of overall findings, the shortened scales could be accepted as brief measure of the inferiority and superiority complex. The overall results may be seen as a contribution to further investigations of Adlerian individual psychology. 


\section{References}

Almagor, M., Tellegen, A., \&Waller, N. G. (1995): The Big Seven Model: A crosscultural replication and further exploration of the basic dimensions of natural language trait descriptors. Journal of Personality and Social Psychology, 69, 300-307.

Costa, P., \& McCrae, R. (1992). Revised NEO Personality Inventory (NEOPI-R) and NEO Five-Factor Inventory (NEO-FFI) professional manual. Odessa, FL: Psychological Assessment Resources, Inc.

Čekrlija, Đ. (2011). Edip u multivarijatnom zagrljaju. Banja Luka: Filozofski fakultet.

Eysenck, H., \& Eysenck, S. (1975). Manual of the Eysenck Personality Questionnaire. San Diego: EdITS/Educational and Industrial Testing Service.

Goldberg, L. R. (1990). An alternative 'Description of Personality': The Big Five factor structure. Journal of Personality and Social Psychology, 59, 1216-1229.

Goldberg, L. R., \& Somer, O. (2000). The hierarchical structure of common Turkish person-descriptive adjectives. European Journal of Personality, 14, 497 - 531.

Gosling, S. D., Rentfrow, P. J., \& Swann, W. B. Jr. (2003). A very brief measure of the Big-Five personality domains. Journal of Research in Personality, 37, 504-528.

Grygier, T. G. (1956). Dynamic Personality Inventory. London: N.F.E.R.

Ignjatović, I., Delić, A., \& Trogrlić, A. (1996). Kanoničke relacije faktora iz Eyseckovog upitnika EPQ (verzija sa 103 ajtema) $i$ ajtema skale infantilne inferiornosti ININ. Paper presented at 44th Annual scientific conference of Serbian psychological Association-Sabor. Vrnjačka Banja, Serbia.

Ignjatović, I., Momirović, K., \& Hošek, A. (1995). Taksonomska efikasnost infantilne inferiornosti, kompleksa inferiornosti i kompleksa superiornosti. In Momirović, K. (Ur.), Psihologija kriminala 2, (pp. 111-133). Beograd: Institut za kriminološka i sociološka istraživanja.

Ignjatović, I., Mitrović, D., Jevremov, T., Knebl. J., Šakotić, J., Kurbalija, D., Vasić, A., Trogrlić, A., \& Bojanić, Ž. (2001). Predlog skale za ispitivanje dimenzije od reaktivnosti do kateksičnosti. Paper presented at conference VII Empirical research in psychology. Belgrade, Serbia. (pp. 45).

Ignjatović, I., \& Višekruna, M. (1996). Kanoničke relacije kompleksa superiornosti i fiksacija libida. Paper presented at conference II Empirical research in psychology. Belgrade, Serbia.

Jevremov, T. (1997). Kanoničke relacije Ajzenkovih skala iz EPQ-103 i skale infantilne inferiornosti (ININ). Paper presented at 45th Annual scientific conference of Serbian psychological Association-Sabor. Tara, Serbia (180).

Jevremov, T. i Todosijević, B. (1998). Relacije iktoidne anksioznosti merene skalom LED i kompleksa superiornosti merenog skalom SUCOMP. Paper presented at 46th Annual scientific conference of Serbian psychological Association-Sabor. Aranđelovac, Serbia (pp. 180). 
John, O. P., \& Srivastava, S. (1999). The Big-Five trait taxonomy: History, measurement, and theoretical perspectives. In L. A. Pervin \& O. P. John (Eds.), Handbook of personality: Theory and research (Vol. 2, pp. 102138). New York: Guilford Press.

Kline, R. B. (2005). Principles and practice of structural equation modeling, New York: The Guilford Press.

Kosanović, B. \& Šakotić, J. (1996): Odnosi dimenzija ličnosti iz Eysenckovog upitnika EPQ-103 i infantilne inferiornosti merene skalom ININ. In L. Genc, \& I. Ignjatović (Eds.), Ličnost u višekulturnom društvu (pp. 138153). Novi Sad: Univerzitet u Novom Sadu.

Lee, K., \& Ashton, M. (2004). Psychometric properties of the HEXACO personality inventory. Multivariate Behavioral Research, 39(2), 329- 358.

Mihić, Lj., \& Mitrović, D. (1996). Merne karakteristike i faktorska struktura skale SUCOMP, saopštenje sa štampanim rezimeom, Paper presented at II Empirical research in psychology. Belgrade, Serbia.

Mihić Lj., Višekruna, M., \& Mitrović, D. (1996). Faktorska analiza skale namenjene merenju kompleksa superiornosti SUCOMP. Paper presented at 44th Annual scientific conference of Serbian psychological Association-Sabor. Vrnjačka Banja, Serbia.

Mitrović, D. (1998). Dimenziona provera egzistencije konstrukata infantilna inferiornost, kompleks inferiornosti i kompleks superiornosti proisteklih iz individualno-psihološke teorije Alfreda Adlera. Unpublished Master thesis. Faculty of philosophy, Novi Sad, Serbia.

Mitrović, D. (2004). Upitnička provera Psihoanalitičkog konstrukta Elektra kompleksa putem upitničke poliemocionalnog načina odgovaranja. Unpublished Doctoral thesis. Faculty of philosophy, Novi Sad, Serbia.

Mitrović, D. i Barišić, T. (1997). Odnosi skale kompleksa superiornosti SUCOMP i Adornove (Kalifornijske) skale F. U Genc, L. \& Ignjatović, I. (Eds.): Ličnost u višekulturnom društvu, 3 (177-184). Novi Sad: Filozofski fakultet, Odsek za psihologiju.

Mitrović, D., Jevremov, T., \& Vasić, A. (1997). Relacije 24 osnove dimenzije iz testova MK-240 i faktora proisteklih iz upitnika FR3. Paper presented at X Kongres of Psychologists of Yugoslavia. Beograd, Serbia.

Mitrović, Trogrlić, B., \& Todosijević, B. (1997). Relacije latentnih dimenzija iz upitnika EPQ i upitnika FR3. Paper presented at X Kongres of Psychologists of Yugoslavia. Beograd, Serbia.

Momirović, K., Džamonja, Z., Hrnjica, S., Ignjatović, I., Mejovšek, M., Radovanović, D., Vuĉinić, B. \& Wolf, B. (1975). Struktura indikatora oralne agresivnosti. Psihologija, 3-4, 95-117.

Momirović, K., Ignjatović, I., Radovanović, D., Mejovšek, M., Horga, S., Hrnjica, S., Džamonja, Z., \& Wolf, B. (1976). Struktura indikatora analne agresivnosti. Psihologija, 1-2, 61-80. 
Momčilov, D., \& Radočaj, S. (1999). Preliminarne norme, osnovni metrijski pokazatelji , relacije sa psihološkim varijablama i nekim spoljašnjim pokazateljima skale SUCOMP. Paper presented at V Empirical research in psychology. Belgrade, Serbia.

Momčilov, D., \& Krpović, Ž. (1995). Zajednička struktura i relacije kompleksa inferiornosti i raptoidne anksioznosti. Paper presented at 44th Annual scientific conference of Serbian psychological Association-Sabor. Vrnjačka Banja, Serbia.

Radočaj, S. \& Vasić, A. (1998). Odnosi anksioznosti kočenja procenjene S-R skalom LED i kompleksa infeoriornosti procenjenog skalom COMPIN-N. 46. Paper presented at 44th Annual scientific conference of Serbian psychological Association-Sabor. Aranđelovac, Serbia.

Robins, R. W., Hendin, H. M., \& Trzesniewski, K. H. (2001). Measuring Global Self-Esteem: Construct Validation of a Single-Item Measure and the Rosenberg Self-Esteem Scale. Personality and Social Psychology Bulletin, 27, 151-161.

Rosenberg, M. (1965). Society and the adolescent self-image. Princeton, NJ: Princeton University Press.

Ruk, Đ., i Momčilov, D. (1996). Relacije između kompleksa superiornosti merenog skalom SUCOMP i Eysenckovih dimenzija ličnsoti EPQ (R'96). In Genc, L. i Ignjatović, I. (Eds.), Ličnost u višekulturalnom duštvu, 3 (pp. 167-176). Novi Sad: Filozofski fakultet.

Saucier, G. (1997). Effects of Variable Selection on the Factor Structure of Person Descriptors. Journal of Personality and Social Psychology, 73, 1296-1312.

Smederevac, S., Mitrović, D. i Čolović, P. (2010). Velikih pet plus dva, primena $i$ interpretacija. Beograd: Centar za primenjenu psihologiju.

Šakotić, J. i Karanjac, J. (1999): Preliminarne norme, osnovni merni pokazatelji i relacije sa psiholopšim varijablama i nekim spoljašnjim kriterijumima skale COMPIN-N. Paper presented at II Empirical research in psychology. Belgrade, Serbia.

Šakotić-Kurbalija, J. (2011). Povezanost zavisnosti u partnerskim odnosima sa kompleksom inferiornosti. Godišnjak Filozofskog fakulteta, Novi Sad.

Šakotić, J., Kurbalija, D. i Barišić, T. (1997): Relacije primarnih faktora iz prostora upitnika EPQ i faktora iz upitnika za ispitivanje kompleksa superiornosti - SUCOMP. Paper presented at X Congres od psychologists of Yugoslavia. Petrovac na moru, Monte Negro.

Šakotić, J., Ruk, Đ. (1997): Relacije primarnih faktora iz prostora upitnika EPQ $i$ faktora iz upitnika za ispitivanje kompleksa inferiornosti - COMPIN. Paper presented at X Congres od psychologists of Yugoslavia. Petrovac na moru, Montenegro.

Štrbac, M., Kosanović, B., \& Vasić, A. (1996). Kanoničke relacije fiksacija libida merenih skalom FR-2 i kompleksa inferiornosti merenog skalom COMPIN. Pedagoška stvranost, 9-10, 647-666. 
Todosijević, B., \& Knebl, J. (1998). Odnosi raptoidne anksioznosti i kompleksa superiornosti. Paper presented at 44th Annual scientific conference of Serbian psychological Association-Sabor. Aranđelovac, Serbia.

Trogrlić, A., \& Veljković, Z. (1999). Preliminarne norme, osnovni merni pokazatelji, relacije sa drugim psihološkim varijablama i spoljašnjim kriterijumima upitnika ININ. Paper presented at V Empirical research in psychology. Belgrade, Serbia.

Višekruna, M., Trogrlić, A. i Vasić, A. (1996). Relacije fiksacija libida merenih skalom FR-2 i infantilne inferiornosti merene skalom ININ. Pedagoška stvarnost, 1-2, 110-125.

Vasić, A., Veljković, Z., i Trogrlić, A. (2005). O skali za merenje kompleksa superiornosti dece starijeg osnovnoškolskog uzrasta. Pedagoška stvarnost, 1-2, 133-159.

Vasić, A., i Radočaj, S. (1998). Odnosi anksioznosti bežanja procenjene S-R skalom BEG $i$ infanitilne inferiornosti procenjene skalom ININ. Paper presented at 44th Annual scientific conference of Serbian psychological Association-Sabor. Aranđelovac, Serbia.

Višekruna, M. (1996). Kanoničke relacije kompleksa inferiornosti i fiksacija libida. Paper presented at conference II empirical research in psychology. Belgrade, Serbia.

Zuckerman, M. (2002). Zuckerman-Kuhlman personality questionaire (ZKPQ): An alternative factorial model. In B. DeRaad, M. Perusini (Eds.), Big five assesment (pp. 377-396). Seatle: Hogrefe anh Hubner Publishers.

\section{Appendix 1.}

Table 5. Inferiority complex scale, COMPIN (Nonvalidated translation)

\begin{tabular}{|l|l|l|l|l|l|}
\hline $\begin{array}{l}\text { 1. I often think that I will fail because of previous } \\
\text { failures. }\end{array}$ & 1 & 2 & 3 & 4 & 5 \\
\hline 2. I look less capable compared to others. & 1 & 2 & 3 & 4 & 5 \\
\hline $\begin{array}{l}\text { 3. Fear of failure sometimes stops me at the very } \\
\text { beggining. }\end{array}$ & 1 & 2 & 3 & 4 & 5 \\
\hline $\begin{array}{l}\text { 4. I am less confident than most of people I know, } \\
\text { because of my previous life. }\end{array}$ & 1 & 2 & 3 & 4 & 5 \\
\hline 5. I fail because I can not manage things & 1 & 2 & 3 & 4 & 5 \\
\hline $\begin{array}{l}\text { 6. I would often ask for help but I don't because I } \\
\text { do not want to bother others. }\end{array}$ & 1 & 2 & 3 & 4 & 5 \\
\hline $\begin{array}{l}\text { 7. When people criticise me, I think: I have done } \\
\text { wrong again. }\end{array}$ & 1 & 2 & 3 & 4 & 5 \\
\hline
\end{tabular}




\begin{tabular}{|l|l|l|l|l|l|}
\hline $\begin{array}{l}\text { 8. I think that others have more competences } \\
\text { then I do. }\end{array}$ & 1 & 2 & 3 & 4 & 5 \\
\hline $\begin{array}{l}\text { 9. I do not know how to use my competences at } \\
\text { the right moment. }\end{array}$ & 1 & 2 & 3 & 4 & 5 \\
\hline $\begin{array}{l}\text { 10. I give up easily, even when others think I am } \\
\text { doing fine. }\end{array}$ & 1 & 2 & 3 & 4 & 5 \\
\hline 11. I often give up even if others support me. & 1 & 2 & 3 & 4 & 5 \\
\hline 12. I do not know my own value. & 1 & 2 & 3 & 4 & 5 \\
\hline $\begin{array}{l}\text { 13. I am not difficult to beat in a discussion, } \\
\text { because my arguments are mostly weak. }\end{array}$ & 1 & 2 & 3 & 4 & 5 \\
\hline $\begin{array}{l}\text { 14. I know that I underestimate myself, but I can } \\
\text { not deal with it. }\end{array}$ & 1 & 2 & 3 & 4 & 5 \\
\hline $\begin{array}{l}\text { 15. I am not good in things that other people } \\
\text { manage easily. }\end{array}$ & 1 & 2 & 3 & 4 & 5 \\
\hline $\begin{array}{l}\text { 16. When I work with others it seems that I am } \\
\text { not good as them. }\end{array}$ & 1 & 2 & 3 & 4 & 5 \\
\hline $\begin{array}{l}\text { 17. Usually my performance is under average } \\
\text { because I do not like to be intrusive. }\end{array}$ & 1 & 2 & 3 & 4 & 5 \\
\hline $\begin{array}{l}\text { 18. I can not express myself and keep the people I } \\
\text { love by my side. }\end{array}$ & 1 & 2 & 3 & 4 & 5 \\
\hline $\begin{array}{l}\text { 19. When I have to show my competences I most } \\
\text { often fail. }\end{array}$ & 1 & 2 & 3 & 4 & 5 \\
\hline $\begin{array}{l}\text { 20. I do not do well, because I do not know how } \\
\text { to make an effort. }\end{array}$ & 1 & 2 & 3 & 4 & 5 \\
\hline $\begin{array}{l}\text { 21. During work I keep telling myself: I won't } \\
\text { make it, so it would be better if }\end{array}$ & 1 & 2 & 3 & 4 & 5 \\
\hline I didn't start at all. & 1 & 2 & 3 & 4 & 5 \\
\hline $\begin{array}{l}\text { 22. I often feel that I will not be able to do what is } \\
\text { expected. }\end{array}$ & 1 & 2 & 3 & 4 & 5 \\
\hline $\begin{array}{l}\text { 23. I like to do one task at a time, because I make } \\
\text { mistakes if I have to deal with two things } \\
\text { simultaneously. }\end{array}$ & 1 & 2 & 3 & 4 & 5 \\
\hline 24. I would change a lot of my characteristics. & 1 & 2 & 3 & 4 & 5 \\
\hline $\begin{array}{l}\text { 25. I do not see things as I would like to, because } \\
\text { I have no luck. }\end{array}$ & 1 & 2 & 3 & 4 & 5 \\
\hline 26. Sometimes I fell very small and helpless. & 1 & 2 & 3 & 4 & 5 \\
\hline $\begin{array}{l}\text { 27. I do not like to make life experiments, because } \\
\text { I rarely manage to do anything at all. }\end{array}$ & 1 & 2 & 3 & 4 & 5 \\
\hline 28. I will never get even close to my idols. & 1 & 5 & 5 \\
\hline
\end{tabular}




\begin{tabular}{|l|l|l|l|l|l|}
\hline $\begin{array}{l}\text { 29. I am easily inhibited by failure and I find it } \\
\text { difficult to go on. }\end{array}$ & 1 & 2 & 3 & 4 & 5 \\
\hline $\begin{array}{l}\text { 30. I often leave a bad impression, although I } \\
\text { would like to change that. }\end{array}$ & 1 & 2 & 3 & 4 & 5 \\
\hline $\begin{array}{l}\text { 31. It is harder to notice my virtues then my } \\
\text { weaknesses. }\end{array}$ & 1 & 2 & 3 & 4 & 5 \\
\hline 32. There are many things that are beyond my reach. & 1 & 2 & 3 & 4 & 5 \\
\hline $\begin{array}{l}\text { 33. I often feel that I am not ready for things that } \\
\text { I have to do. }\end{array}$ & 1 & 2 & 3 & 4 & 5 \\
\hline 34. I underestimate my abilities. & 1 & 2 & 3 & 4 & 5 \\
\hline 35. I do not respect myself enough. & 1 & 2 & 3 & 4 & 5 \\
\hline 36. I am not self-confident. & 1 & 2 & 3 & 4 & 5 \\
\hline $\begin{array}{l}\text { 37. I never talk to people first because I do not } \\
\text { know how to do it. }\end{array}$ & 1 & 2 & 3 & 4 & 5 \\
\hline $\begin{array}{l}\text { 38. When somebody compliments me, I know it } \\
\text { is just good manners. }\end{array}$ & 1 & 2 & 3 & 4 & 5 \\
\hline 39. I can not say no even when it is necessary. & 1 & 2 & 3 & 4 & 5 \\
\hline $\begin{array}{l}\text { 40. I tend to attribute my failures to various } \\
\text { circumstances. }\end{array}$ & 1 & 2 & 3 & 4 & 5 \\
\hline
\end{tabular}

\section{Appendix 2.}

Table 6. Superiority complex scale, SUCOMP (Nonvalidated translation)

\begin{tabular}{|l|l|l|l|l|l|}
\hline 1. It is in my nature to be successful. & 1 & 2 & 3 & 4 & 5 \\
\hline $\begin{array}{l}\text { 2. I am always leading conversation even when I } \\
\text { am tired of it.. }\end{array}$ & 1 & 2 & 3 & 4 & 5 \\
\hline $\begin{array}{c}\text { 3. I can win against anybody if I put my mind to } \\
\text { it. }\end{array}$ & 1 & 2 & 3 & 4 & 5 \\
\hline $\begin{array}{c}\text { 4. People can always learn something clever } \\
\text { from me. }\end{array}$ & 1 & 2 & 3 & 4 & 5 \\
\hline $\begin{array}{c}\text { 5. I am sure people talk about me because I have } \\
\text { a strong personality. }\end{array}$ & 1 & 2 & 3 & 4 & 5 \\
\hline $\begin{array}{c}\text { 6. Life would be much better if people would } \\
\text { think and work like I do. }\end{array}$ & 1 & 2 & 3 & 4 & 5 \\
\hline $\begin{array}{c}\text { 7. When I do something, it is important to me to } \\
\text { be the best, and I mostly manage to be. }\end{array}$ & 1 & 2 & 3 & 4 & 5 \\
\hline $\begin{array}{c}\text { 8. Even wnen others think differently, my } \\
\text { conclusions are better. }\end{array}$ & 1 & 2 & 3 & 4 & 5 \\
\hline
\end{tabular}




\begin{tabular}{|l|l|l|l|l|l|}
\hline 9. My way of thinking is very original. & 1 & 2 & 3 & 4 & 5 \\
\hline $\begin{array}{l}\text { 10. People often say I am wrong, but no one can } \\
\text { prove it. }\end{array}$ & 1 & 2 & 3 & 4 & 5 \\
\hline $\begin{array}{l}\text { 11. People can not find any flaw in my character, } \\
\text { unless they are malicious. }\end{array}$ & 1 & 2 & 3 & 4 & 5 \\
\hline $\begin{array}{l}\text { 12. I think most people could learn a lot from } \\
\text { me. }\end{array}$ & 1 & 2 & 3 & 4 & 5 \\
\hline $\begin{array}{l}\text { 13. I can withstand and work more than most } \\
\text { people. }\end{array}$ & 1 & 2 & 3 & 4 & 5 \\
\hline $\begin{array}{l}\text { 14. Those who are friends with me gain } \\
\text { prominence as well. }\end{array}$ & 1 & 2 & 3 & 4 & 5 \\
\hline $\begin{array}{l}\text { 15. I know that other people secretly admire me, } \\
\text { even if they deny it. }\end{array}$ & 1 & 2 & 3 & 4 & 5 \\
\hline 16. I am always efficient when doing something. & 1 & 2 & 3 & 4 & 5 \\
\hline $\begin{array}{l}\text { 17. Few people have had as much success as I } \\
\text { have. }\end{array}$ & 1 & 2 & 3 & 4 & 5 \\
\hline 18. Few people can compare with me. & 1 & 2 & 3 & 4 & 5 \\
\hline $\begin{array}{l}\text { 19. What is just an ordinary thing to me, many } \\
\text { people would consider success. }\end{array}$ & 1 & 2 & 3 & 4 & 5 \\
\hline 20. No one works better than me. & 1 & 2 & 3 & 4 & 5 \\
\hline $\begin{array}{l}\text { 21. Normally no solution can be found without } \\
\text { me. }\end{array}$ & 1 & 2 & 3 & 4 & 5 \\
\hline $\begin{array}{l}\text { 22. Those who have achieved as much as I have } \\
\text { had to try harder. }\end{array}$ & 1 & 2 & 3 & 4 & 5 \\
\hline $\begin{array}{l}\text { 23. Sometimes I don't fulfill my own } \\
\text { expectations, but I know that others would } \\
\text { not achieve even that much. }\end{array}$ & 1 & 2 & 3 & 4 & 5 \\
\hline $\begin{array}{l}\text { 24. I wasn't successful only when I didn't care } \\
\text { about it.. }\end{array}$ & 1 & 2 & 3 & 4 & 5 \\
\hline $\begin{array}{l}\text { 25. I am not afraid of arguments because I know } \\
\text { that my opinion will be the correct one. }\end{array}$ & 1 & 2 & 3 & 4 & 5 \\
\hline $\begin{array}{l}\text { 26. Real knowledge is gained by experience; I } \\
\text { have enough experience and so do not need } \\
\text { the opinion and advice of others. }\end{array}$ & 1 & 2 & 3 & 4 & 5 \\
\hline $\begin{array}{l}\text { 27. The worst thing would be if there weren't } \\
\text { people like me. }\end{array}$ & 1 & 2 & 3 & 4 & 5 \\
\hline 28. Charm is one of my powers. & 1 & 2 & 3 & 4 & 5 \\
\hline $\begin{array}{l}\text { 29. When I want something, I make it clear to } \\
\text { everybody. }\end{array}$ & 1 & 2 & 3 & 4 & 5 \\
\hline
\end{tabular}




\begin{tabular}{|l|l|l|l|l|l|}
\hline $\begin{array}{l}\text { 30. When I explain something, no more } \\
\text { explanation is required. }\end{array}$ & 1 & 2 & 3 & 4 & 5 \\
\hline $\begin{array}{l}\text { 31. People rarely make fun of me because they } \\
\text { know that I can retaliate. }\end{array}$ & 1 & 2 & 3 & 4 & 5 \\
\hline $\begin{array}{l}\text { 32. I have never failed yet because I was always } \\
\text { ready for anything. }\end{array}$ & 1 & 2 & 3 & 4 & 5 \\
\hline 33. I know what I want and that I can get it. & 1 & 2 & 3 & 4 & 5 \\
\hline $\begin{array}{l}\text { 34. My assessment is always the most correct so } \\
\text { far. }\end{array}$ & 1 & 2 & 3 & 4 & 5 \\
\hline 35. I am rarely disturbed by anything. & 1 & 2 & 3 & 4 & 5 \\
\hline 36. I rarely miss a chance to show my advantage. & 1 & 2 & 3 & 4 & 5 \\
\hline $\begin{array}{c}\text { 37. I am interested in many things and that sets } \\
\text { me apart from other people.. }\end{array}$ & 1 & 2 & 3 & 4 & 5 \\
\hline $\begin{array}{c}\text { 38. I know that people feel honoured by my } \\
\text { presence, even if they do not want to admit it. }\end{array}$ & 1 & 2 & 3 & 4 & 5 \\
\hline
\end{tabular}




\section{VALIDACIJA SKRAĆENIH SKALA ADLEROVSKOG KOMPLEKSA INFERIORNOSTI (COMPIN) I SUPERIORNOSTI (SUCOMP)}

Rezime: Glavni cilj ovog istraživanja jeste da se preispitaju skale za kompleks inferiornosti, odnosno superiornosti, i da se kreiraju njihove skraćene verzije. U to svrhu, sprovedene su dve studije. Prva studija je obuhvatila 395 studenata (62\% ženskog pola), a analizirane su skale kompleksa inferiornosti (COMPIN, 40 stavki) i superiornosti (SUCOMP, 38 stavki). Ispitivanje psihometrijskih karakteristika pokazalo je da su psihometrijske osobine skala zadovoljavajuće. Na osnovu vrednosti komunaliteta, ajtem-total korelacije i zasićenosti glavnog komponenta skale, za skraćene verzije je izabrano po deset stavki. Eksploratorna faktorska analiza skraćenih skala jasno je ukazala na dva faktora koji prestavljaju kompleks inferiornosti, odnosno superiornosti. Uzorak druge studije obuhvatio je 187 studenata ( $53 \%$ ženskog pola), i na njemu je urađena je konfirmativna faktorska analiza. Strukturalni model se sastoji od dve prepoznatljive, korelirane dimenzije i od odgovarajućih fit indikatora. $\mathrm{Na}$ osnovu rezultata u celini, možemo zaključiti da se adlerovski pojmovi mogu adekvatno operacionalizovati pomoću skala COMPIN i SUCOPM. Ove skale mogu biti važni instrumenti u psiholoških istraživanjima. Takođe, skraćene skale COMPIN-10 i SUCOMP-10 korisni instrumenti za merenje kompleksa inferiornosti, odnosno superiornosti.

KLJUČNE REČI: kompleks inferiornosti i superiornosti, COMPIN i SUCOMP skale, validacija. 